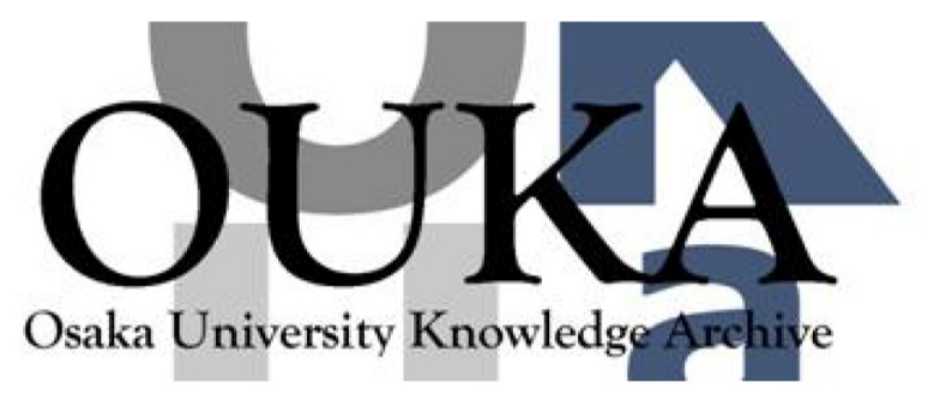

\begin{tabular}{|c|l|}
\hline Title & $\begin{array}{l}\text { Human peripheral blood polymorphonuclear } \\
\text { leukocytes at the ovulatory period are in an } \\
\text { activated state }\end{array}$ \\
\hline Author(s) & Shirai, F \\
\hline Citation & \\
\hline Issue Date & \\
\hline oaire:version & VoR \\
\hline URL & https://hdl. handle. net/11094/44508 \\
\hline rights & \\
\hline Note & \\
\hline
\end{tabular}

Osaka University Knowledge Archive : OUKA

https://ir. Library. osaka-u. ac. jp/

Osaka University 


\title{
Human peripheral blood polymorphonuclear leukocytes at the ovulatory period are in an activated state
}

\author{
F. Shirai ${ }^{\text {a }}$, M. Kawaguchi ${ }^{a}$, M. Yutsudo ${ }^{\text {b }}$, Y. Dohi ${ }^{\text {a,* }}$ \\ ${ }^{\text {a }}$ Division of Allied Health Sciences, Department of Microbiology and Infectious Diseases, Osaka University Medical School, 1-7 Yamada-oka, Suita, \\ Osaka 565-0871, Japan \\ ${ }^{\mathrm{b}}$ Department of Tumor Virology, Research Institute for Microbial Diseases, Osaka University, Suita, Japan
}

Received 19 March 2002; accepted 17 July 2002

\begin{abstract}
The ovulatory process has been compared with inflammation. We investigated the state of female peripheral polymorphonuclear leukocytes (PMN) during menstrual cycles, and found that PMN contained high levels of superoxide, hydrogen peroxide and nitric oxide (NO) during at the peri-ovulatory period. Assuming the cause of this elevation to be a luteinizing hormone (LH), the surge of which preceded the ovulation, we examined the responsiveness of PMN to pituitary LH. The results revealed that this hormone elevated dose-dependently the production of reactive oxygen intermediates (ROI). Furthermore, we demonstrated the mRNA expression of LH receptors and their presence on PMN. The data indicated that the LH surge before on the ovulatory day resulted in general activation of PMN, suggesting that this state of PMN may be a necessary step for initiation of ovulation, rather than a defensive role against infection. (C) 2002 Elsevier Science Ireland Ltd. All rights reserved.
\end{abstract}

Keywords: Neutrophil; Ovulation; Luteinizing hormone receptor; Superoxide; Nitric oxide

\section{Introduction}

It is generally believed that polymorphonuclear leukocyte (PMN) is the first line of defense against bacterial infections. During the course of evaluating reactive oxygen intermediates (ROI) production by peripheral blood resident PMN of healthy volunteers, we found female values $\left(0.000-4.942 \mathrm{nmole} / 2 \times 10^{6}\right.$ PMN) more deviated than males $(0.000-0.555$ nmole/ $2 \times 10^{6} \mathrm{PMN}$ ). Considering this, we tried to elucidate the possibility that ovulation may influence ROI production of PMN, because there were many reports to suggest that the ovulatory process in the ovary resembled an inflammatory reaction (Espey, 1980; Takehara et al., 1994).

These hypotheses depend on the observation of infiltration of leukocytes in the ovary and the production of inflammatory mediators such as TNF- $\alpha$ and IL$1 \beta$ apparently also participating in this process (Brann-

* Corresponding author. Tel./fax: +81-6-6879-2552

E-mail address: dohi@sahs.med.osaka-u.ac.jp (Y. Dohi). strom et al., 1993a,b; Hurwitz et al., 1991; Takehara et al., 1994). At the peri-ovulatory period rat leukocytes were reported to be localized in the ovaries (Brannstrom et al., 1993a,b), and leukocyte supplementation increased the LH-induced ovulation rate in the in vitroperfused rat ovary (Hellberg et al., 1991). Furthermore, administration of a neutrophil-depleting monoclonal antibody reduced the ovulation rate in the rat (Brannstrom et al., 1995). Therefore, leukocytes may play an important role in ovulation. In addition, Polan et al. reported that ovarian steroids modulated the mRNA production of TNF- $\alpha$ and IL-1 $\beta$ on cultured peripheral monocytes (Loy et al., 1992; Polan et al., 1989, 1990). However, as the release of many kinds of hormones and cytokines may concomitantly be involved in ovulation (Hellberg et al., 1991), it may induce general phenomena rather than a localized reaction to the ovary, although ovulation does neither accompany a fever, nor leukocytosis. Conversely, the state of peripheral PMN at the peri-ovulatory period could influence the ovary. Therefore, we analyzed the states of peripheral blood PMN at the period during a menstrual cycle. 
It was reported that ovulation occurred at the 34-38 $\mathrm{h}$ following the plasma onset of the luteinizing hormone (LH) surge (Andersen et al., 1995; Testart and Frydman, 1982; Testart et al., 1981), which consequently triggered ovulation (Cunnigham et al., 1997). Therefore, it is worth examining whether the LH molecules would also influence PMN at non-ovulatory periods. The degrees of activation of LH-primed PMN could be evaluated by comparing those of anti-Fc $\gamma \mathrm{R}(\mathrm{CD} 16)$ antibody-primed $\mathrm{PMN}$, the incubation of which should result in general activation of PMN.

Receptors for LH (LHR) have been reported to be expressed on various organs and tissues (Dufau, 1998). However, its expression on PMN is unknown. Thus, we have tried to ascertain the mRNA expression of LHR on PMN by RT-PCR. Furthermore, expression of LHR on the surface of PMN was examined by the specific binding of ${ }^{125} \mathrm{I}$-labeled LH to PMN.

It is well-known that triggering of Fc $\gamma \mathrm{R}$ of PMN induces ROI production and kills phagocytized bacteria, but it is quite unclear what triggering of LHR on PMN induces. Roles of PMN that have been activated through LHR on the ovulatory day were discussed.

\section{Materials and methods}

\subsection{Subjects}

Twenty non-pregnant, non-infected (that is, no fever, no leukocytosis, no leukopenia and no recent anamnesis

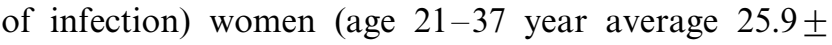
5.61) were subjected to this examination. The average menstrual cycle was $29.1 \pm 2.69$ days and the duration of menstruation was 5-8 days. Informed consent was provided by all subjects.

\subsection{Hormones, chemicals and antibodies}

Human pituitary LH, human chorionic gonadotropin (hCG), follicle-stimulating hormone (FSH) and scopoletin were purchased from Sigma Chemical Co., St. Louis, MO. Luminol, horseradish peroxidase (HPO), bovine erythrocyte- $\mathrm{Cu}, \mathrm{Zn}$-containing superoxide dismutase (SOD) and carboxy-2-phenyl-4,4,5,5-tetra-methyl-imidazoline-1-oxyl-3-oxide (carboxy-PTIO) were purchased from Wako Chemical Industry, Tokyo, Japan. Dextran T500, Percoll and Gene images ${ }^{\text {TM }}$ were purchased from Amarsham Pharmacia Biotech AB, Uppsala, Sweden. Hanks balanced salt solution without phenol red was purchased from GIOBCO BRL, Life Sciences, Gaithersgurg, MD. SV Total RNA Isolation System was purchased from Promega Corp., Madison, WI. Premix Taq was purchased from Takara Shuzo Co., Ltd., Otsu, Japan. THERMOSCRIPT ${ }^{\mathrm{TM}}$ RT-PCR System was purchased from Life Technologies,
GIBCO BRL, Glasgow, Scotland, UK. Human ovary cDNA purchased from Clontech, Palo Alto, CA. Human $\mathrm{LH} / \mathrm{hCG}$ receptor cDNA was a generous gift from Dr Takashi Minegishi at Gunma University, Maebashi, Japan (Minegishi et al., 1990). Iodine-125 Radionuclide (NEZ-033H) was purchased from NEN ${ }^{\mathrm{TM}}$ Life Science Products, Inc. Boston, MA. Anti-Fc $\gamma \mathrm{R}(\mathrm{CD} 16, \mathrm{IgG} 1 \kappa$,

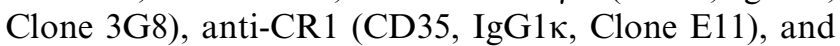
anti-CR3 (CD11b, IgG1 $\kappa$, Clone BEAR1) mAbs were purchased from Pharmingen, San Diego, CA.

\subsection{Determination of ovulatory period}

Ovulatory period of young women was predicted by following these three procedures: (1) Survey on basal body temperature. (2) Check for urine LH concentration by 'L-check' plates (Nipro, Tokyo, Japan) to be a higher value than $40 \mathrm{IU} / 1$ that would expect ovulation within 48 h. (3) Ultrasonographic observation of disappearance of a large dominant follicle from the ovary. Ovulation was determined principally by all three procedures per one subject.

\subsection{Purification of peripheral blood polymorphonuclear leukocytes}

Heparinized blood was subjected in 5\% Dextran T500 sedimentation, and its supernatant fraction was layered on top of the discontinuous gradients $(75,70$ and $60 \%$ ) of Percoll, and then centrifuged for $15 \mathrm{~min}$ at $800 \times \mathrm{g}$. The cells from the layer of PMN were collected. This fraction contained about $98 \%$ of neutrophils, $2 \%$ of other types of granulocytes and none of lymphocytes, as judged under a microscope after Giemsa staining. In all experiments, leukocytes were counted in Turk's reagent.

\subsection{Determination of superoxide, hydrogen peroxide and nitric oxide content of PMN}

The resident (untreated) and/or stimulated states of PMN were examined for superoxide, hydrogen peroxide and nitric oxide (NO) production. In some experiments, PMN were stimulated through the incubation with $1 \mu \mathrm{g} /$ $\mathrm{ml} \mathrm{mAbs}$ (anti-Fc $\gamma \mathrm{R}$, anti-CR1 and/or anti-CR3) or 40$160 \mathrm{mIU} / \mathrm{ml} \mathrm{LH}, \mathrm{hCG}$ or FSH. Hydrogen peroxide was measured by Andreae's scopoletin procedure (Andreae, 1995). Briefly, scopoletin was converted to non-fluorescent oxidized scopoletin by reacting it with hydrogen peroxide and HPO. The fluorescence (excitation wavelength, $350 \mathrm{~nm}$; emission wavelength, $460 \mathrm{~nm}$ ) was monitored with a recording spectrofluoro-photometer (model RF-1500, Shimadzu Co. Ltd., Kyoto, Japan). During these determinations, we added sodium azide to a final concentration of $1 \mathrm{mM}$ to block the catalase and myeloperoxidase of PMN (Root et al., 1975; Root and Metcalf, 1977). We previously confirmed that $1 \mathrm{mM}$ 
sodium azide did not inhibit HPO and SOD at all (Root and Metcalf, 1977; Nauseef et al., 1983). For the estimation of superoxide, final $50 \mu \mathrm{g} / \mathrm{ml}$ of SOD were added to convert the superoxide to hydrogen peroxide. Superoxide production was evaluated as the increase in amount of hydrogen peroxide generated by SOD. NO was measured by a luminol-dependent chemiluminescence procedure described elsewhere (Catz et al., 1995). Briefly, $1 \times 10^{5} \mathrm{PMN}$ were incubated at $37{ }^{\circ} \mathrm{C}$ in the phenol red-free Hanks balanced salt solution supplemented with $20 \mathrm{mM}$ HEPES buffer $\mathrm{pH} 7.4$, and luminol solution were admixed at the final concentration of 5 $\mu \mathrm{M}$. In some tubes, $100 \mathrm{mM}$ carboxy-PTIO was presupplemented to scavenge NO. To estimate the amounts of $\mathrm{NO}$, the total chemiluminescence values were subtracted the values in the presence of carboxy-PTIO (Wanikiat et al., 1997; Pryor and Squadrito, 1995). Chemiluminescence emission was monitored with a recording luminescence leader (Model BLR-201, Aloka Co.Ltd., Tokyo, Japan).

\subsection{RT-PCR and southern hybridization}

Total RNA was extracted from PMN by guanidine thiocyanate and $\beta$-mercaptoethanol (Sambrook et al., 1989). A reverse transcription (RT) reaction was carried out $\left(50{ }^{\circ} \mathrm{C} 50 \mathrm{~min}\right)$, followed by a denaturation period of $5 \mathrm{~min}$ at $85{ }^{\circ} \mathrm{C}$. Thereafter, a polymerase chain reaction (PCR) with 40 cycles $\left(94{ }^{\circ} \mathrm{C}\right.$ for $30 \mathrm{~s}, 55{ }^{\circ} \mathrm{C}$ for $30 \mathrm{~s}$, and $68{ }^{\circ} \mathrm{C}$ for $1 \mathrm{~min}$, with a final extension period of $7 \mathrm{~min}$ at $68{ }^{\circ} \mathrm{C}$ ) was performed. The sense primer corresponded to nucleotides 170-190 (exon2) of the LHR gene and the antisense primer, to nucleotides 1026-1045 (exon11) (nucleotides are numbered from the initiation ATG). And then, a nested PCR with 30 cycles $\left(94{ }^{\circ} \mathrm{C}\right.$ for $30 \mathrm{~s}, 55{ }^{\circ} \mathrm{C}$ for $30 \mathrm{~s}$, and $68{ }^{\circ} \mathrm{C}$ for $1 \mathrm{~min}$, with a final extension period of $7 \mathrm{~min}$ at $68{ }^{\circ} \mathrm{C}$ ) was performed. The sense primer corresponded to nucleotides 386-405 (exon5) and antisense primer, to nucleotides 952-971 (exon11). As a positive control for RT and PCR, ASY/Nogo-B gene (Li et al., 2001) and human ovary cDNA were subjected, respectively. As negative controls for RT, experiments were done without addition of the RNA fraction or the enzyme. After nested PCR, amplification DNA fragments were electrophoresed in $2 \%$ agarose gel. After blotted on a nylon membrane (Biodyne, Pall BioSupport, East Hills, NY), southern hybridization was done by using an alkaline phosphatase enzyme labeled oligonucleotide probe, which corresponded to nucleotides 575-816 of LHR cDNA, to confirm the specificity of these PCR products. The amplified PCR products were confirmed their sequence by a DNA sequencer (310 Genetic Analyzer, Applied Biosystems Japan Co.Ltd., Tokyo, Japan).

\subsection{Scatchard analysis of $L H$ receptor to PMN}

LH was labeled with iodine-125 by Chloramin T procedure (Dohi and Nisonoff, 1979). Specific activity of the labeled compound was $3.39 \times 10^{4} \mathrm{cpm} / \mathrm{ng}$. PMN were resuspended in HBSS supplemented with $1 \mathrm{mM}$ sodium azide, $1 \mathrm{mM}$ EDTA and/or $10 \mathrm{mM} \mathrm{KCN}$ to minimize destruction of activated PMN with LH. PMN of $1 \times 10^{5}$ were mixed with various concentrations of labeled $\mathrm{LH}$, incubated for $30 \mathrm{~min}$ at $0{ }^{\circ} \mathrm{C}$ and washed with phosphate buffered saline by centrifugation. Resulting precipitates were counted with a $\gamma$-counter (ARC-380, Aloka Co. Ltd., Tokyo, Japan). To exclude non-specific binding of labeled LH to the PMN, we subtracted the values in the presence of about 1000 -fold excess of hCG from the binding values.

\subsection{Statistical analyses}

Data are presented as the mean \pm S.E. The analyses were performed with a statistical package (STAT FLEX Ver.5.0). The normality of the distribution of the data was evaluated by the Bartlett test. When the data are normally distributed, the parametric one-way analysis of variance (ANOVA), and when not normally distributed, the non-parametric Kruskal-Wallis test, were utilized, and followed a Scheffe's multiple range test. $P<0.05$ was considered significant.

\section{Results}

\subsection{The content of superoxide, hydrogen peroxide and nitric oxide of peripheral blood PMN at the peri- ovulatory period}

We examined superoxide and hydrogen peroxide content of female peripheral blood resident PMN during a menstrual cycle (Fig. 1). Ovulatory day was expected as described in Section 2. Particularly high levels of the sum amounts of superoxide and hydrogen peroxide were detected at the peri-ovulatory period. As shown in Fig. 2, ROI was particularly detectable in high levels at the 3 days of the period and the difference of the value was significant $(P<0.01)$. We also evaluated NO production during the menstruation cycle. The result showed the very high NO production only at the ovulatory day and the difference of the values was significant $(P<$ 0.01) (Fig. 3). These results indicated that peripheral PMN were in an activated state particularly at the periovulatory period. 

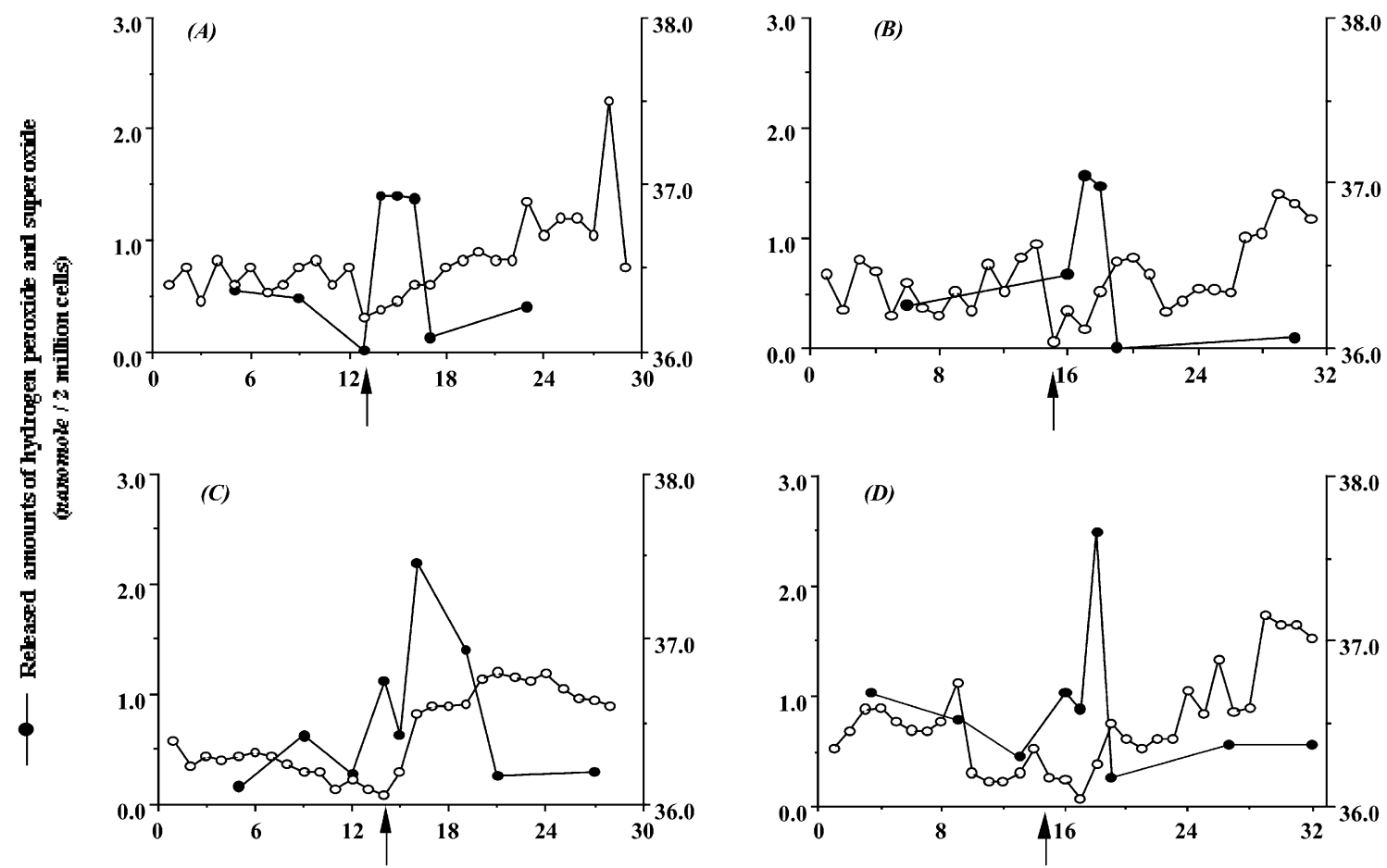

Days after menstruation started

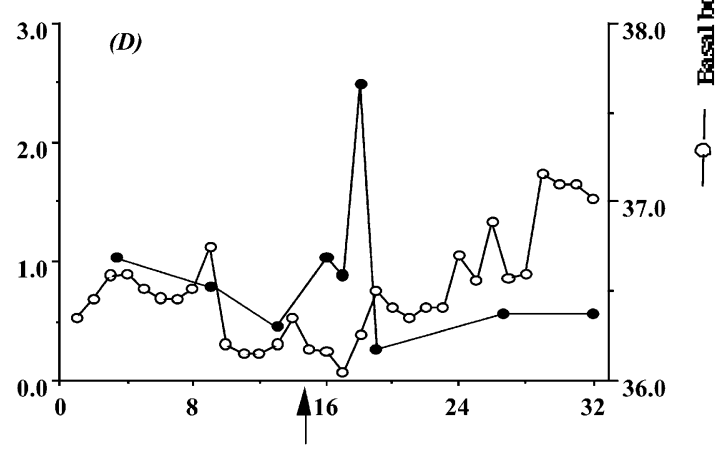

Days after menstruation started

Fig. 1. Released amounts of ROI by peripheral blood PMN during a menstrual cycle (four cases, A to D). The arrow indicated the day when urinary LH concentration was $>40$ IU/l. ( $)$ indicated released amounts of ROI, and $(\bigcirc)$ showed basal body temperature.

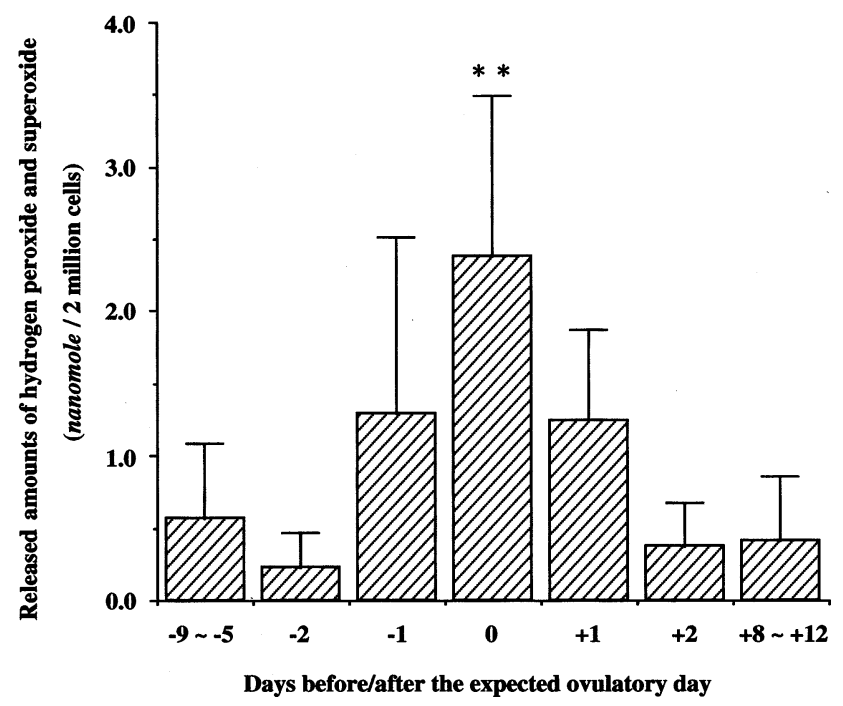

Fig. 2. High levels of ROI content of PMN were especially detectable at the 3 days of peri-ovulatory period. Ovulatory day was expected as described in Section 2. The values are expressed as the mean \pm S.E. $(n=10) .{ }^{* *}$, Significantly higher $(P<0.01)$ than menstrual phase $(-9$ to -5 days), peri-ovulatory phase $(-2$ and +2 days) and luteal phase $(+8$ to +12 days $)$.

\subsection{Peripheral blood leukocyte count}

The significant differences in the number of peripheral blood leukocytes were not seen in a menstrual cycle (Fig. 4).

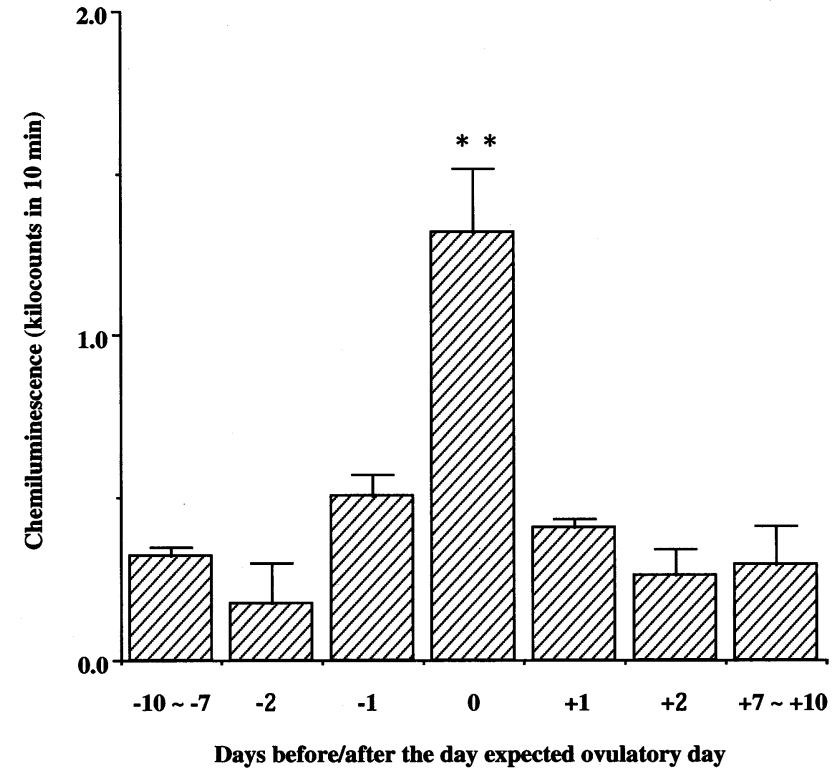

Fig. 3. A high level of NO content of PMN was detected only at the ovulatory day. The values are expressed as the mean \pm S.E. $(n=7)$. **, Significantly higher $(P<0.01)$ than menstrual phase $(-10$ to -7 days), peri-ovulatory phase $(-2,-1,+1$ and +2 days $)$ and luteal phase $(+7$ to +10 days $)$.

\subsection{In vitro response of superoxide and $N O$ production of $P M N$ to $L H$}

We attempted to activate PMN at the pre-ovulatory period with the pituitary LH. The luminol-dependent 


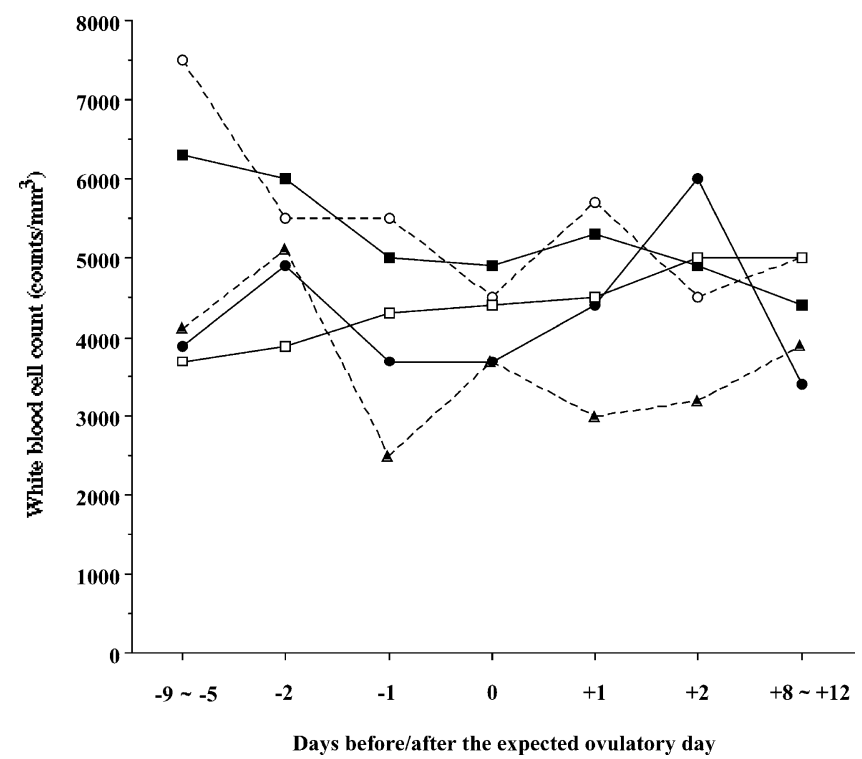

Fig. 4. Peripheral blood leukocyte count during a menstrual cycle. Values of five individuals $(\bigcirc \square \square \Delta)$ were shown.

chemiluminescence of the PMN products was evaluated in the absence and presence of carboxy-PTIO, a NO scavenger. The difference of these values is dependent on the amounts of produced NO. As shown in Fig. 5, content of the fraction in the presence of carboxy-PTIO increased dose-dependently with LH in $10 \mathrm{~min}$. However, neither hCG nor FSH at the similar dose increased the superoxide content. Thus, the elevation appeared to be restricted to LH. Furthermore, the levels brought by
$40-80 \mathrm{mIU} / \mathrm{ml}$ of $\mathrm{LH}$ were similar to those by antiCD16 and anti-CD35, or anti-CD16 and anti-CD11b monoclonal antibodies $(1 \mu \mathrm{g} / \mathrm{ml}$ each). NO production was not significantly increased in a LH-dose dependent manner.

\section{4. $m R N A$ expression of receptors for $L H$ ( $L H R)$ on $P M N$}

To assess LHR expression in PMN, RT-PCR and hybridization analysis of LHR mRNA was performed on peripheral PMN in pre-ovulatory and ovulatory phase. The results indicated that the nested PCR products in either phase of three cases amplified 586 bp band, which was the same as human ovary cDNA, and no bands amplified in negative controls (Fig. 6). Human ovary cDNA, but not PMN cDNA also amplified 397 and 687 bp bands, which may corresponded to spliced forms of the mRNA (Minegishi et al., 1990). The RT-PCR products were confirmed their DNA sequences.

\subsection{Scatchard analysis for binding of $L H$ to $L H R$}

In order to determine the number of binding sites of LH on PMN, Scatchard analysis was carried out with the ${ }^{125}$ I-labeled LH. The experiments were done in lower concentration of the labeled LH than $0.2 \mu \mathrm{g} / \mathrm{ml}$ due to the higher concentration lysed PMN. When estimating nonspecific binding of labeled LH, 1000-fold excess of

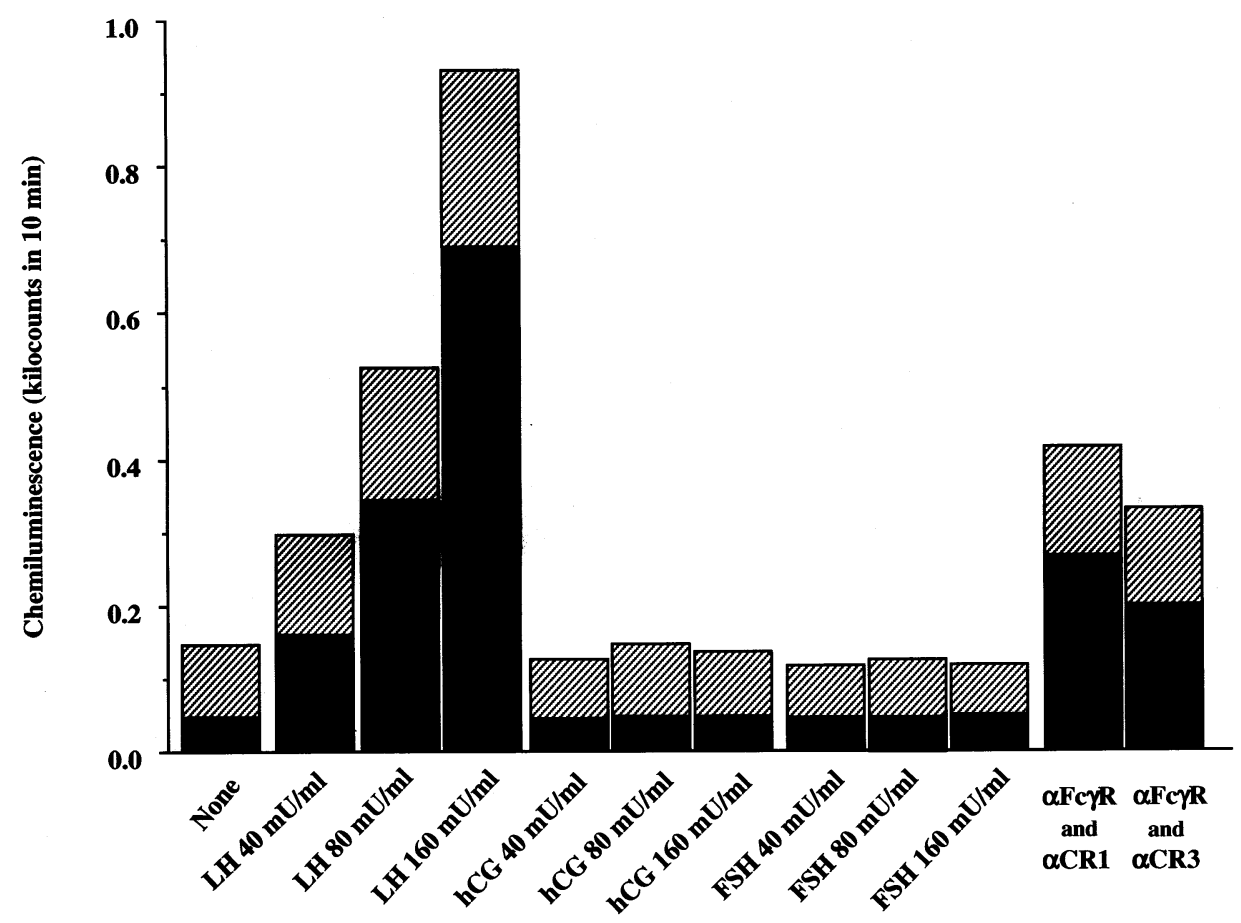

Fig. 5. Response of resident PMN to LH, hCG or FSH. Menstrual phase PMN (6 days after menstruation started) were incubated in vitro with LH, hCG, FSH $(40-160 \mathrm{mIU} / \mathrm{ml})$ or $\mathrm{mAbs}(1 \mu \mathrm{g} / \mathrm{ml})$. The hatched bars showed NO production, and the closed bars showed ROI production. 


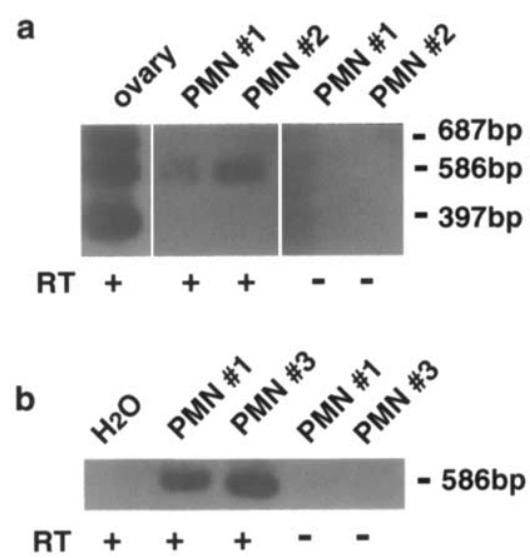

Fig. 6. LHR mRNA expression in PMN or ovary. RNA was extracted from PMN, electrophoresed, blotted, and hybridized with the labeled LH cDNA probe. (a) Ovary mRNA, pre-ovulatory phase of PMN $(\# 1)$ and ovulatory phase of PMN (\#2). Ovary cDNA was subjected as a positive control. (b) Ovulatory phase of PMN (\#3). Samples omitted of the RNA $\left(\mathrm{H}_{2} \mathrm{O}\right)$ or the RT enzyme (RT-) were used as negative controls.

unlabeled hCG were previously incubated with the PMN. hCG did not lyse PMN probably because of a lack of activation of PMN (Fig. 5), but was reported to have the same binding site as LH (Dufau, 1998). The results indicated that average 17000 binding sites of $\mathrm{LH}$ were extrapolated to be expressed on one PMN (Fig. 7).

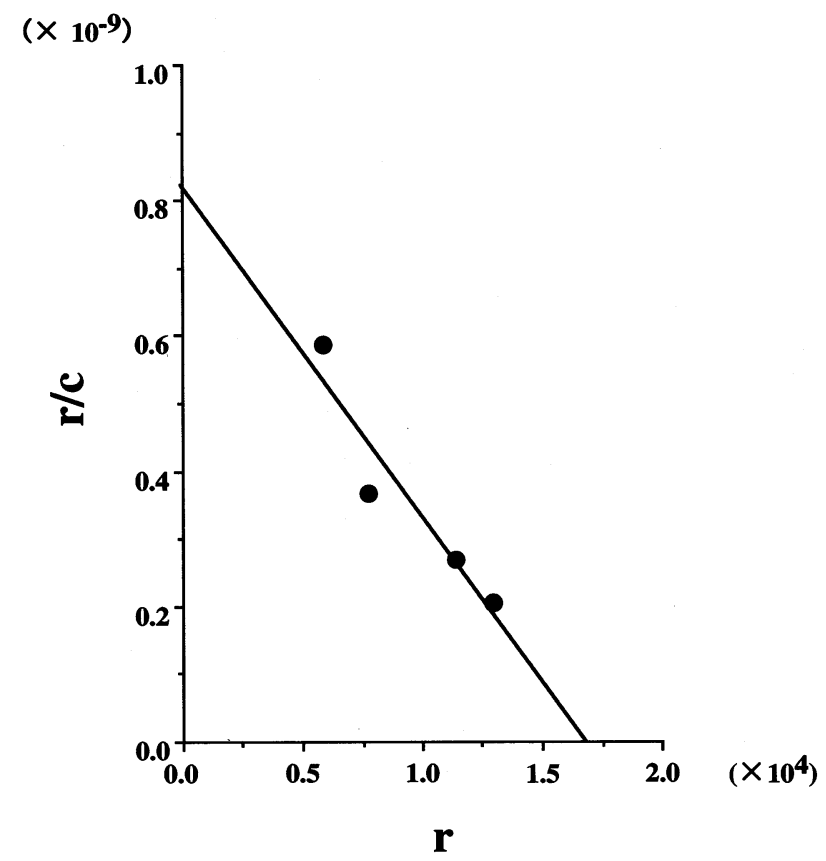

Fig. 7. Scatchard analysis of LH receptors on PMN. PMN were assayed for binding with increasing amounts of ${ }^{125} \mathrm{I}$-labeled $\mathrm{LH}$ and a constant amount of unlabeled hCG in a total volume of $0.1 \mathrm{ml}$. Data was plotted according to Scatchard, giving a $K a=4.88 \times 10^{9}$ per M. $r$ represents number of $\mathrm{LH}$ molecules bound to one cell, assuming that the molecular weight of LH was 29000 . $c$ represents molar concentration of LH. Each point is the average of triplicate determinations.
The association constant for the binding was estimated as $4.88 \times 10^{9}$ per $\mathrm{M}$.

\section{Discussion}

We have demonstrated that human peripheral blood PMN, particularly at the peri-ovulatory period, contained high levels of superoxide and NO, and that the pituitary $\mathrm{LH}$, enhanced the superoxide levels of PMN in vitro. The superoxide production was triggered by $\mathrm{LH}$, but not by hCG or FSH. These results suggested that the production of high levels of superoxide by PMN may play an important role in ovulation. Tamate $\mathrm{K}$ et al. showed histochemically SOD in granulosa, theca and luteal cells in the human ovary (Tamate et al., 1995). Superoxide and hydrogen peroxide appeared to mediate luteolysis and ovulation. Although, it is unclear from where these materials were produced (Wang et al., 1993).

We also clarified the mRNA expression of receptors for LH (LHR) on the PMN. To our knowledge, there are no reports for the existence of LHR on PMN, although LHR have been reported to be detected on many organs and tissues, including ovary, testis, uterus, placenta, salpinx, brain and lymphocytes (Dufau, 1998; Lin et al., 1995). RT-PCR and nested PCR experiments were carried out. A band of $586 \mathrm{bp}$, which hybridized to LHR cDNA, was detected in the products of PMN, indicating the expression of LHR mRNA on PMN (Fig. 6). However, human ovary cDNA amplified not only a $586 \mathrm{bp}$ band, but also 397 and 687 bp bands. The latters may correspond to spliced forms of the mRNA (Minegishi et al., 1990; Reinholz et al., 2000).

We enumerated the number of binding sites of LH on PMN by Scatchard plots. High dose of ${ }^{125}$ I-labeled LH let PMN to be autolysed. As shown in Fig. 5, higher doses of LH induced high levels of ROI. Thus we could not get values in lower r/c points. However, four points of Scatchard plots showed a straight line, the slope of which indicated that the association constant $K a$ was about $4.88 \times 10^{9}$ per $\mathrm{M}$. The extrapolated value in $\mathrm{X}$ axis indicated about 17000 LHR per cell (Fig. 7). These values were close to the reported: that is, the $K a$ between hCG and the rat ovarian receptors, $6.20 \times 10^{9}$ per M (Roche and Ryan, 1989) and 20000 LHR per cell on rat Leydig cells (Dufau and Catt, 1978).

The binding of LH to LHR triggered ROI formation in a short time (Fig. 5), suggesting the presence of another pathway to activate NADPH oxidase, similarly as the mechanism via FcR (Chanock et al., 1994; DeLeo et al., 1999; Miller and Britigan, 1997; Segal and Jones, 1979). LH, but not by hCG or FSH activated PMN. These three hormones are composed of two subunits, $\alpha$ and $\beta$ : the $\alpha$-subunits are identical and the $\beta$-subunits are different for the different hormones. It is the $\beta$ - 
subunit that determines the specific activity of each hormone (Dufau, 1998; Lapthorn et al., 1994; Wu et al., 1994). Our data showed that $40 \mathrm{mU} / \mathrm{ml}$ of $\mathrm{LH}$ resulted in PMN activation, but $160 \mathrm{mU} / \mathrm{ml}$ of hCG and $\mathrm{FSH}$ did not (Fig. 5). This may reflect the difference of $\beta$ subunit of each hormone. But there is a report that hCG administration induced ovulation in vivo (Andersen et al., 1995; Testart and Frydman, 1982; Testart et al., 1981). In their in vivo experiments, other signals may be included.

There are many reports that NO played important roles on ovulation (Faletti et al., 1999; Mitsube et al., 1999). NO might maintain the state of ovarian vasorelaxation required to accommodate the ovulatory increase in blood flow, blood volume and plasma exudation (Bonello et al., 1996). Therefore, we examined NO content of PMN during a menstrual cycle and NO production by LH (Figs. 3 and 5). The unexpectedly high level of NO content was detected on PMN particularly on the ovulatory day. This result suggested that PMN exposed to LH surge prior to ovulatory day would induce iNOS, which could consequently catalyze NO production. Our data is coincides with a recent report by Mitsube $\mathrm{K}$ et al., that showed the expression of iNOS in the LH-primed ex-vivo perfused rat ovary by immuno-blotting, though they did not show which kinds of cells were expressed in the ovary (Mitsube et al., 1999). NO production of PMN to increased concentration of LH was not observed. This suggests that these cases of NO production might be catalyzed by a constitutional enzyme eNOS (Forstermann et al., 1998), because the induction of iNOS would take more than $8 \mathrm{~h}$ (Stuehr and Marletta, 1987).

Products of inflammatory leukocytes had shown to play a role in the process of follicle rupture (Brannstrom and Janson, 1991). It was reported that on the in vitroperfused LH-primed rat ovary, but not on the nonprimed ovary, the addition of leukocytes markedly potentiated the ovulation response (Hellberg et al., 1991). It would be postulated that the perfused LH bound to PMN within the ovary. As LH-bound PMN resulted in production of superoxide and $\mathrm{NO}$, these PMN may greatly contribute to the process of follicle rupture.

The regular bacterial infections accompany luekocytosis, but a significant luekocytosis was not observed during a menstrual cycle (Fig. 4). Furthermore, we did not find significant difference in the levels of the ROI in the presence of 500-fold excess of heat-killed Staphylococcus aureus among a menstrual cycle (data not shown). Considering the humoral and cytokine networks of ovulatory process, the temporal activation of PMN at ovulatory period may be a physiologic event for the induction of follicle rupture, rather than a defensive one against infection.

\section{Acknowledgements}

We are grateful for helpful discussion throughout this work from Dr Kenji Yamaji at our Osaka University Medical School and Dr Takashi Minegishi at Gunma University School of Medicine for generous gift of a plasmid containing human LHR cDNA.

\section{References}

Andersen, A.G., Als-Nielsen, B., Hornnes, P.J., Franch Andersen, L., 1995. Time interval from human chorionic gonadotrophin (HCG) injection to follicular rupture. Hum. Reprod. 10, 3202-3205.

Andreae, W.A., 1995. A sensitive method for the estimation of hydrogen peroxide in biological materials. Nature 175, 859-860.

Bonello, N., McKie, K., Jasper, M., Andrew, L., Ross, N., Braybon, E., Brannstrom, M., Norman, R.J., 1996. Inhibition of nitric oxide: effects of on interleukin-1 $\beta$-enhanced ovulation rate, steroid hormones, and ovarian leukocyte distribution at ovulation in the rat. Biol. Reprod. 54, 436-445.

Brannstrom, M., Janson, P.O., 1991. Biochemistry of ovulation. In: Hillier, S. (Ed.), Ovarian Endocrinology. Blackwell, Oxford, pp. $132-166$.

Brannstrom, M., Mayrhofer, G., Robertson, S.A., 1993. Localization of leukocyte subsets in the rat ovary during the periovulatory period. Biol. Reprod. 48, 277-286.

Brannstrom, M., Wang, L., Norman, R.J., 1993. Ovulatory effect of interleukin- $1 \beta$ on the perfused rat ovary. Endocrinology 132, 399404.

Brannstrom, M., Bonello, N., Norman, R.J., Robertson, S.A., 1995. Reduction of ovulation rate in the rat by administration of a neutrophil-depleting monoclonal antibody. J. Reprod. Immunol. 29, 265-270.

Catz, S.D., Carreras, M.C., Poderoso, J.J., 1995. Nitric oxide synthase inhibitors decrease human polymorphonuclear leukocyte luminoldependent chemiluminescence. Free Radic. Biol. Med. 19, 741748 .

Chanock, S.J., Benna, J.E.I., Smith, R.M., Babior, B.M., 1994. The respiratory burst oxidase. J. Biol. Chem. 269, 24519-24522.

Cunnigham, F.G., MacDonald, P.C., Gant, N.F., Leveno, K.J., Gilstrap, I.I.I.L.C., Hankins, G.D.V., Clark, S.L., 1997. Physiology of pregnancy. In: Licht, J. (Ed.), Williams Obstetrics, 20th ed.. Appleton \& Lange, Connecticut, pp. 69-93.

DeLeo, F.R., Allen, L.A.H., Apicella, M., Nauseef, W.M., 1999. NADPH oxidase activation and assembly during phagocytosis. J. Immunol. 163, 6732-6740.

Dohi, Y., Nisonoff, A., 1979. Suppression of idiotype and generation of suppressor T cells with idiotype-conjugated themocytes. J. Exp. Med. 150, 909-918.

Dufau, M.L., 1998. The luteinizing hormone receptor. Annu. Rev. Physiol. 60, 461-496.

Dufau, M.L., Catt, K.J., 1978. Gonadotropin receptors and regulation of steroidogenesis in testis and ovary. Vitam. Horm. 36, 461-592.

Espey, L.L., 1980. Ovulation as an inflammatory reaction - a hypothesis. Biol. Reprod. 22, 73-106.

Faletti, A., Perez, M.S., Perotti, C., de-Gimeno, M.A., 1999. Activity of ovarian nitric oxide synthase (NOs) during ovulatory process in the rat: relationship with prostagrandins (PGs) production. Nitric Oxide 3, 340-347.

Forstermann, U., Boissel, J.P., Kleinert, H., 1998. Expressional control of the constitutive isoforms of nitric oxide synthase (NOSI and NOSIII). FASEB J. 12, 773-790.

Hellberg, P., Thomsen, P., Janson, P.O., Brannstrom, M., 1991. Leukocyte supplementation increases the luteinizing hormone- 
induced ovulation rate in the in vitro-perfused rat ovary. Biol. Reprod. 44, 791-797.

Hurwitz, A., Ricciarelli, E., Botero, L., Rohan, R.M., Hernandez, E.R., Adashi, E.Y., 1991. Endocrine-and autocrine-mediated regulation of rat ovarian (theca-interstitial) interleukin-1 $\beta$ gene expression: gonadotropin-dependent preovulatory acquisition. Endocrinology 129, 3427-3429.

Lapthorn, A.J., Harris, D.C., Littlejohn, A., Lustbader, J.W., Canfield, R.E., Machin, K.J., Morgan, F.J., Isaacs, N.W., 1994 Crystal structure of human chorionic gonadotropin. Nature 369, 455-461.

Li, Q., Qi, B., Oka, K., Shimakage, M., Yoshika, N., Inoue, H., Hakura, A., Kodama, K., Stanbridge, E.J., Yutsudo, M., 2001. Link of a new type apoptosis-inducing gene $A S Y / N o g o-B$ to human cancer. Oncogene 20, 3929-3936.

Lin, J., Lojun, S., Lei, Z.M., Wu, W.X., Peiner, S.C., Rao, C.V., 1995. Lymphocytes from pregnant women express human chorionic gonadotropin/luteinizing hormone receptor gene. Mol. Cell. Endocrinol. 111, R13-R17.

Loy, R.A., Loukides, J.A., Polan, M.L., 1992. Ovarian steroids modulate human monocyte tumor necrosis factor alpha messenger ribonucleic acid levels in cultured human peripheral monocytes. Fertil. Steril. 58, 733-739.

Miller, R.A., Britigan, B.E., 1997. Role of oxidants in microbial pathophysiology. Clin. Microbiol. Rev. 10, 1-18.

Minegishi, T., Nakamura, K., Takakura, Y., Miyamoto, K., Hasegawa, Y., Ibuki, Y., Igarashi, M., 1990. Cloning and sequencing of human LH/hCG receptor cDNA. Biochem. Biophys. Res. Commun. 172, 1049-1054.

Mitsube, K., Mikuni, M., Matousek, M., Brannstrom, M., 1999. Effects of a nitric oxide donor and nitric oxide synthase inhibitors on luteinizing hormone-induced ovulation in the ex-vivo perfused rat ovary. Hum. Reprod. 14, 2537-2543.

Nauseef, W.M., Metcalf, J.A., Root, R.K., 1983. Role of myeloperoxidase in the respiratory burst of human neutrophils. Blood 61 , 483-492.

Polan, M.L., Loukides, J., Nelson, P., Carding, S., Diamond, M., Walsh, A., Bottomly, K., 1989. Progesterone and estradiol modulate interleukin-1 $\beta$ messenger ribonucleic acid levels in cultured human peripheral monocytes. J. Clin. Endocrinol. Metab. 69, 1200-1206.

Polan, M.L., Kuo, A., Loukides, J., Bottomly, K., 1990. Cultured human luteal peripheral monocytes secrete increased levels of interleukin-1. J. Clin. Endocrionol. Metab. 70, 480-484.

Pryor, W.A., Squadrito, G.L., 1995. The chemistry of peroxynitrite: a product from the reaction of nitric oxide with superoxide. Am. J. Physiol. 268, L699-L722.

Reinholz, M.M., Zschunke, M.A., Roche, P.C., 2000. Loss of alternately spliced messenger RNA of the luteinizing hormone receptor and stability of the follicle- stimulating hormone receptor messenger RNA in granulosa cell tumors of the human ovary. Gynecol. Oncol. 79, 264-271.

Roche, P.C., Ryan, R.J., 1989. Purification, characterization, and amino-terminal sequence of rat ovarian receptor for luteinizing hormone/human choriogonadotropin. J. Biol. Chem. 264, 46364641.

Root, R.K., Metcalf, J.A., 1977. $\mathrm{H}_{2} \mathrm{O}_{2}$ release from human granulocytes during phagocytosis. Relationship to superoxide anion formation and cellular catabolism of $\mathrm{H}_{2} \mathrm{O}_{2}$ : studies with normal and cytochalasin B-treated cells. J. Cin. Invest. 60, 1266-1279.

Root, R.K., Metcalf, J., Oshino, N., Chance, B., 1975. $\mathrm{H}_{2} \mathrm{O}_{2}$ release from human granulocytes during phagocytosis. I. Documentation, quantitation, and some regulating factors. J. Clin. Invest. 55, $945-$ 955.

Sambrook, J., Fritsch, E.F., Maniatis, T., 1989. Extraction, purification, and analysis of messenger RNA from eukaryotic cells. In: Noland, C. (Ed.), Molecular Cloning a Laboratory Manual, second ed.. Cold Spring Harbor Laboratory, New York, pp. 7.1-7.87.

Segal, A.W., Jones, O.T., 1979. The subcellular distribution and some properties of the cytochrome $\mathrm{b}$ component of the microbicidal oxidase system of human neutrophils. Biochem. J. 182, 181-188.

Stuehr, D.J., Marletta, M.A., 1987. Induction of nitrite/nitrate synthesis in murine macrophages by BCG infection, lymphokines, or interferon-gamma. J. Immunol. 139, 518-525.

Takehara, Y., Dharmarajan, A.M., Kaufman, G., Wallach, E.E., 1994. Effect of interleukin-1 $\beta$ on ovulation in the in vitro perfused rabbit ovary. Endocrinology 134, 1788-1793.

Tamate, K., Sengoku, K., Ishikawa, M., 1995. The role of superoxide dismutase in the human ovary and fallopian tube. J. Obstet. Gynaecol. 21, 401-409.

Testart, J., Frydman, R., 1982. Minimum time lapse between luteinizing hormone surge or human chorionic gonadotropin administration and follicular rupture. Fertil. Steril. 37, 50-53.

Testart, J., Frydman, R., Feinstein, M.C., Thebault, A., Roger, M., Scholler, R., 1981. Interpretation of plasma luteinizing hormone assay for the collection of mature oocytes from women: definition of a luteinizing hormone surge-initiating rise. Fertil. Steril. 36, 5054.

Wang, F., Riley, J.C.M., Behrman, H.R., 1993. Immunosuppressive levels of glucocorticoid block extrauterine luteolysins in the rat. Biol. Reprod. 49, 66-73.

Wanikiat, P., Woodward, D.F., Armstrong, R.A., 1997. Investigation of the role of nitric oxide and cyclic GMP in both the activation and inhibition of human neutrophils. Br. J. Pharmacol. 122, 11351145.

Wu, H., Lustbader, J.W., Liu, Y., Canfield, R.E., Hendrickson, W.A., 1994. Structure of human chorionic gonadotropin at $2.6 \AA$ resolution from MAD analysis of the selenomethionyl protein. Structure 2, 545-558. 